\title{
The generation and analysis of a novel combination of recombinant adenovirus vaccines targeting three tumor antigens as an immunotherapeutic
}

\author{
Kwong Y Tsang ${ }^{1 *}$, Elizabeth S Gabitzsch², Claudia Palena ${ }^{3}$, Justin M David ${ }^{3}$, Massimo Fantini ${ }^{1}$, Anna R Kwilas ${ }^{1}$, \\ Adrian E Rice ${ }^{2}$, Yvette Latchman², James W Hodge ${ }^{1}$, Caroline Jochems ${ }^{1}$, Romaine I Fernando ${ }^{3}$, James Gulley ${ }^{4}$, \\ Ravi A Madan', Christopher R Heery ${ }^{3}$, Joseph P Balint ${ }^{2}$, Frank R Jones², Jeffrey Schlom ${ }^{1}$
}

From 30th Annual Meeting and Associated Programs of the Society for Immunotherapy of Cancer (SITC 2015) National Harbor, MD, USA. 4-8 November 2015

We have reported on a novel adenovirus serotype 5 (Ad5) vector gene delivery platform (Ad5 [E1-, E2b-]), in which regions of the early 1 (E1), early 2 (E2b), and early 3 (E3) genes have been deleted. The unique deletions in this platform result in a dramatic decrease in late gene expression, leading to a marked reduction in host immune response to the vector. CEA, MUC1, and brachyury are tumor-associated antigens (TAA) expressed on a wide range of human tumors. Ad5 [E1-, E2b-]-CEA vaccine (ETBX011) has been employed in clinical studies as an active vaccine to induce immune responses to CEA in metastatic colorectal cancer patients. The Ad5 [E1-, E2b-]-CEA vector encodes the entire CEA sequence modified to express an enhancer T-cell epitope. We report here the development of novel Ad5 [E1-, E2b-]-brachyury and Ad5 [E1-, E2b-]-MUC-1 vaccine constructs. The Ad5 [E1-, E2b-]brachyury vector was constructed to encode the entire brachyury gene devoid of 25 amino acids involved in DNA binding, and modified to express an enhancer $\mathrm{T}$ cell epitope. The Ad5 [E1-, E2b-]-MUC-1 vector was constructed to encode the entire MUC-1 transgene with eight agonist epitopes, including five in the C-terminus. Our results show that these constructs (CEA, MUC1 and brachyury) are capable of activation, as well as generation of antigen specific $\mathrm{T}$ cells in vitro, and of inducing antigen-specific $\mathrm{T}$ cells in vaccinated mice. We have also demonstrated that the use of a combination of the three vaccines (designated Tri-Ad5) displays little, if any, antigenic competition in in vitro studies of human dendritic cells for antigen-specific $\mathrm{T}$ cell activation and generation, or in murine vaccination

National Cancer Institute, National Institutes of Health, Bethesda, MD, USA Full list of author information is available at the end of the article studies. The studies reported here support the rationale for the application of Tri-Ad5 as a therapeutic modality to induce immune responses to a diverse range of human TAAs for potential clinical studies.

\section{Authors' details}

${ }^{1}$ National Cancer Institute, National Institutes of Health, Bethesda, MD, USA 2Etubics Corporation, Seattle, WA, USA. ${ }^{3}$ Laboratory of Tumor Immunology and Biology, Center for Cancer Research, National Cancer Institute, National Institutes of Health, Bethesda, MD, USA. ${ }^{4}$ Genitourinary Malignancies Branch National Cancer Institute, National Institutes of Health, Bethesda, MD, USA.

Published: 4 November 2015

doi:10.1186/2051-1426-3-S2-P452

Cite this article as: Tsang et al:: The generation and analysis of a novel combination of recombinant adenovirus vaccines targeting three tumor antigens as an immunotherapeutic. Journal for ImmunoTherapy of Cancer 2015 3(Suppl 2):P452.

Submit your next manuscript to BioMed Central and take full advantage of:

- Convenient online submission

- Thorough peer review

- No space constraints or color figure charges

- Immediate publication on acceptance

- Inclusion in PubMed, CAS, Scopus and Google Scholar

- Research which is freely available for redistribution 